\title{
Embryonic loss, abortion, and malformations in ewes caused by the ingestion of hay leaves of Cenostigma pyramidale ${ }^{1}$
}

\author{
Suélen D.S. Reis ${ }^{2}$, Juliana T.S.A. Macêdo ${ }^{3}$, Ariana L. Pereira ${ }^{3}$, Rubens S. Jesus ${ }^{5}$, \\ Luciano A. Pimentel ${ }^{4}$, Ivo Pivato ${ }^{6}$, Tiago C. Peixoto ${ }^{2,7}$ (D) \\ and Pedro M.O. Pedroso ${ }^{2,3 *}$ (D)
}

\begin{abstract}
Reis S.D.S., Macêdo J.T.S.A., Pereira A.L., Jesus R.S., Pimentel L.A., Pivato I., Peixoto T.C. \& Pedroso P.M.O. 2020. Embryonic loss, abortion, and malformations in ewes caused by the ingestion of hay leaves of Cenostigma pyramidale. Pesquisa Veterinária Brasileira 40(10):750-757. Universidade Federal da Bahia, Av. Adhemar de Barros 500, Ondina, Salvador, BA 40170-110, Brazil. E-mail: pedrosovet@yahoo.com.br

Determining if reproductive failures in ewes at the semiarid region in the state of Bahia are related to the consumption of the species Cenostigma pyramidale (Tul.) Gagnon \& G.P. Lewis, and this study was developed using pregnant ewes divided into six groups: G1, G2, G3, G4 with six animals each, G5 and G6 with ten animals. Each group received fence leaves in the proportion of $1 \%, 2 \%, 0.5 \%$, and $0.25 \%$ of live weight (LW) respectively; G5 and G6, with ten animals each, receiving $0.25 \%$ and $0.5 \%$ of the LW, respectively, and the Control Group, comprising 16 ewes, were grass feeding (Cynodon dactylon). Ewes from G1 to G4 were the same, except for two, and started ingestion of the plant four days after ending of natural mating on the 80th day of gestation, while those regarding from G5 to G6 groups started ingestion on the 26th day of gestation ending on the 98 day. The ultrasonographic test was performed weekly. In G1 ewes (1\%), there was an embryonic loss on the 32nd and 39th days of gestation and abortion on the 46th day. In G2 (2\%), the embryo loss was earlier (on the 26th day of gestation), and abortion on the 46th day of gestation. In G3 group (0.5\%), there was an embryonic loss around the 40th day of gestation. In G4 group ( $0.25 \%)$, it was observed the occurrence of one death lamb with bone malformations. In G6 (0.5\%), abortion occurred later (108 days), followed by retained placenta. This was also verified in G5 group $(0.25 \%)$. The presence of fetal malformation was found in death lambs born in G4 group, born alive from G5 and G6 groups, and one aborted from G6. In G5 and G6 groups, there were also genetic alterations on surviving lambs. In addition to these results, recurrent estrus was observed without gestation in G1, G2, G3, and G4 ewes. From the Control Group, 13 normal lambs were born without genetic alterations; furthermore, concerning a quadruple birth, three lambs were born dead. The results infer that species of C. pyramidale in low doses causes reproductive losses in pregnant ewes, therefore it is not recommended for sheep diet over the first 60 days of gestation.
\end{abstract}

INDEX TERMS: Embryonic loss, abortion, malformation, ewes, Cenostigma pyramidale, hay, reproductive losses, teratogenic plant, sheep, catingueira.

\footnotetext{
${ }^{1}$ Received on April 13, 2020.

Accepted for publication on April 27, 2020.

${ }^{2}$ Graduate Program in Animal Science in the Tropics (PPGCAT), Universidade Federal da Bahia (UFBA), Av. Adhemar de Barros 500, Ondina, Salvador, BA 40170-110, Brazil.

${ }^{3}$ Laboratório de Patologia Veterinária, Fundação Universidade de Brasília (UnB), Campus Universitário Darcy Ribeiro, Via L4 Norte $s \backslash n$, Brasília, DF 70910-970, Brazil. *Corresponding author: pedrosovet@yahoo.com.br

${ }^{4}$ Setor de Patologia Veterinária, Hospital Universitário de Medicina Veterinária, Universidade Federal do Recôncavo da Bahia (UFRB), Rua Rui Barbosa 710, Campus Universitário, Cruz das Almas, Bahia, BA 44380-000, Brazil.
}

\footnotetext{
${ }^{5}$ Setor de Clínica e Cirurgia de Grandes Animais, Hospital Universitário de Medicina Veterinária, Universidade Federal do Recôncavo da Bahia (UFRB), Rua Rui Barbosa 710, Campus Universitário, Cruz das Almas, Bahia, BA 44.380-000, Brazil.

${ }^{6}$ Laboratório de Reprodução Animal, Fundação Universidade de Brasília (UnB), Campus Universitário Darcy Ribeiro, Via L4 Norte $s \backslash n$, Brasília, DF 70910-970, Brazil.

${ }^{7}$ Laboratório de Patologia Veterinária, Universidade Federal da Bahia (UFBA), Av. Adhemar de Barros 500, Ondina, Salvador, BA 40170-110, Brazil.
} 
RESUMO.- [Perda embrionária, aborto e malformações em ovinos por ingestão de Cenostigma pyramidale na forma fenada.] Para determinar se falhas reprodutivas em ovelhas na região semiárida da Bahia estão relacionadas ao consumo de Cenostigma pyramidale (Tul.) Gagnon \& G.P. Lewis, foi realizado um estudo utilizando-se ovelhas prenhes divididas em seis grupos e dois Grupos Controle. Os grupos G1, G2, G3 e G4 com seis animais cada. Cada grupo recebeu folhas fenadas na proporção de $1 \%, 2 \%, 0,5 \%$ e $0,25 \%$ do peso vivo (PV) respectivamente; G5 e G6, com 10 animais cada, que receberam $0,25 \%$ e $0,5 \%$ do PV respectivamente. Os Grupos Controle foram alimentados com ração e capim (Cynodon dactylon). Ovelhas dos grupos 1 a 4 iniciaram ingestão da planta quatro dias após monta natural com término aos 80 dias de gestação, enquanto as dos grupos 5 a 6 iniciaram ingestão no $26^{\circ}$ dia de gestação com término aos 98 dias. Avaliação ultrassonográfica foi realizada semanalmente. Nos animais do G1 (1\%), verificouse perda embrionária aos 32 e 39 dias de gestação, e aborto aos 46 dias. Nos do G2 (2\%) a perda embrionária foi mais precoce (26 dias), e aborto aos 46 dias. No G3 (0,5\%), houve perda embrionária em torno dos 40 dias. No G4 (0,25\%), verificou-se ocorrência de natimorto com malformações aos 150 dias de gestação. No G6 (0,5\%) o aborto ocorreu mais tardiamente (108 dias), seguido de retenção de placenta. Essa ocorrência também foi verificada no G5 $(0,25 \%)$. A presença de malformação fetal foi encontrada em fetos natimorto do G4, nascidos vivos do G5 e G6, e um abortado do G6. No G5 e G6 também foram observadas alterações de aprumos em cordeiros sobreviventes. Do Grupo Controle nasceram 13 borregos normais, porém uma ovelha apresentou gestação quádrupla com três natimortos. Os resultados inferem que $C$. pyramidale fenada em baixas doses causa perdas reprodutivas em ovelhas gestantes, não sendo por isso recomendada para a dieta de ovelhas durante os primeiros 60 dias de gestação.

TERMOS DE INDEXAÇÃO: Perda embrionária, aborto, malformações, ovinos, Cenostigma pyramidale, feno, perdas reprodutivas, planta teratogênica, ovelhas, catingueira.

\section{INTRODUCTION}

The association between the consumption of toxic plants and the occurrence of reproductive changes in farm animals is known in Brazil and other countries (Panter et al. 1990, Pimentel et al. 2007, Welch et al. 2009). The reported toxic effects result in miscarriages, embryonic loss, embryonic resorption and teratogeny.

Concerning the Northeast region of Brazil, where goat breeding is an important economic activity and source of income, the abortive and teratogenic effects of Mimosa tenuiflora, also known as "jurema-preta", have been proven to be harmful both in ruminants and in rats (Nóbrega Júnior et al. 2005, Pimentel et al. 2007, Medeiros et al. 2008, Dantas et al. 2010, Santos et al., 2012). Additionally, Cenostigma pyramidale (Poincyanella pyramidalis) (Tul.) Gagnon \& G.P. Lewis is teratogenic for goats (Reis et al. 2016), rats (Câmara et al. 2017), and sheep (Lopes et al. 2017).

Based on reports of malformation outbreaks and abortions in small ruminants in the state of Bahia, an experiment was carried out to verify whether hay leaves of $C$. pyramidale (hay) induces reproductive failures in pregnant ewes at different gestational periods.

\section{MATERIALS AND METHODS}

Stages. The experiment was divided into three Stages. Stages 1 and 2 were performed at the "Universidade Federal do Recôncavo da Bahia" (UFRB), from March to December 2016. Stage 3 was conducted at the "Universidade de Brasília" (UnB), from September 2016 to January 2017. In each of the three Stages, two treatment groups (G) were formed. In Stage 1, groups G1 and G2 were formed, while stage 2 was composed of G3 and G4 groups, and Stage 3, by G5 and G6 groups. The Animal Use Ethics Committee approved this study of the UFRB (protocol number 23007.013398 / 2012-21).

Animals. To conduct the experiment, 50 Santa Inês, Bergamácia, and crossbred ewes, aged from one to five years, were chosen. Of these animals, 14 underwent treatment in Stages 1 and 2, 20 were distributed in stage 3, and 16 comprised the Control Group. Semen was collected from four sheep aged from two to three years (three Santa Inês and one Bergamácia) for artificial insemination and natural breeding.

Treatment and Control Groups. Six treatment groups were randomly set up (G1, G2, G3, G4, G5, and G6), in addition to two Control Groups. Groups 1-4 were made up of six ewes each, and groups 5-6 were made up of 10 ewes each. Groups 1, 2, 3, 4, 5, and 6 received daily doses of Cenostigma pyramidale (Tul.) Gagnon \& G.P. Lewis (hay leaves) of concentrations of $1 \%, 2 \%, 0.5 \%, 0.25 \%$, $0.25 \%$ and $0.5 \%$. The females used were examined clinically and submitted to ultrasound evaluation to rule out pregnancy and changes in the reproductive system before starting treatment. Males were subjected to andrological evaluation before semen collection and natural breeding (NB). Leaves of $C$. pyramidale were harvested in the rural area of the municipalities of Tupiaçu and Geolândia in the region of Recôncavo Bahiano. After harvesting, leaves were stored to dry in the shade for 10 to 15 days. After desiccated, the leaves were crushed and bagged according to the animal's weight $(\mathrm{g} / \mathrm{kg}$ of live weight (LV)). A sample of the specimen plant was authenticated and deposited at the Herbarium of the "Universidade Estadual de Feira de Santana" (UEFS) under number (HUEFS 240996).

The negative pregnancy was confirmed by ultrasonography (USG) through the rectum (SonoScape device, $7.0 \mathrm{MHz}$ ); a short synchronization protocol was performed. On the day 0 , intravaginal sponges impregnated with $60 \mathrm{mg}$ of medroxyprogesterone acetate (MAP) (Progespon ${ }^{\circledR}$, Laboratório Syntex S.A.) were inserted. Equine chorionic gonadotropin (eCG PMSG-Novormon ${ }^{\circledR} 5000$ UI, Zoetis-Pfizer, 2.0IU/animal) prostaglandin (Sincrocio ${ }^{\circledR}$, OuroFino, $0.6 \mathrm{ml} /$ animal) were administered intramuscularly on the 5 th day. On the 6 th day, the sponges were removed. The NB occurred on the 7 th, 9 th, and 10th days, and on the 8th day, Fixed-Time Artificial Insemination (FTAI) with fresh semen was performed (Fig.1). The ewes were placed in individual stalls, and after four days, that is, counted from the last natural mount, a daily supply of dried and ground leaves of C. pyramidale was initiated for ewes in Stages 1 and 2 (G1-G4) until the 80th day of gestation. Ewes in groups 5-6 could ingeste the hay leaves from the 26th day of gestation until the 98th day of gestation (Fig.2).

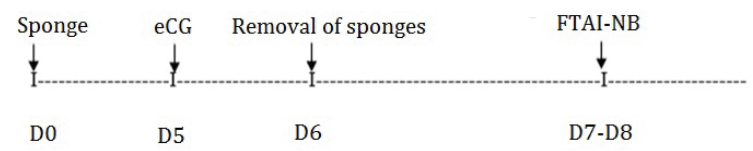

Fig.1. Short protocol regarding the synchronization and artificial insemination in a fixed time period. Fixed-Time Artificial Insemination (FTAI), natural breeding (NB). 
Animals that were not pregnant, that is, suffered embryonic loss or abortion remained in the treatment groups, being together with the others. Concentrate and mineral salt was added to the dried and ground leaves of $C$. pyramidale to adjust the acceptability. Any residues found in the troughs were collected and weighed. After the total consumption of dry and ground leaves, the ewes received grass or silage until the end of the afternoon.

The USG was performed weekly to monitor the gestational evolution. In addition, weights were checked weekly to update the quantities of dried leaves and leaves on the ground to be administered. Ewes, that have more than one estrus or "heat", were again subjected to NB. In case of abortion or stillbirth lambs, necropsy and, when possible, radiological examinations were performed.

\section{RESULTS}

Regarding Stage 1, in G1 group (1\% LW of hay leaves), there was embryonic loss in three ewes on the 32nd day of gestation and also on the 39th days, while in G2 (2\% LW of hay leaves), two ewes suffered embryonic loss on the 32nd and 26th days, respectively. Abortion occurred in one ewe in G1 and one in G2 group on the 46th days of gestation (Table 1).

Pregnancy confirmation was performed by USG on the 20th day after FTAI, as well as confirming evidence of embryonic loss and abortion (Table 1 and Fig.3). One G1 and two G2 animals returned to estrus 18 days after coating covering, again submitted to NB, remaining non-pregnant. The ewes, that suffered embryonic loss or abortion after ingesting hay

Experimental design in three stages

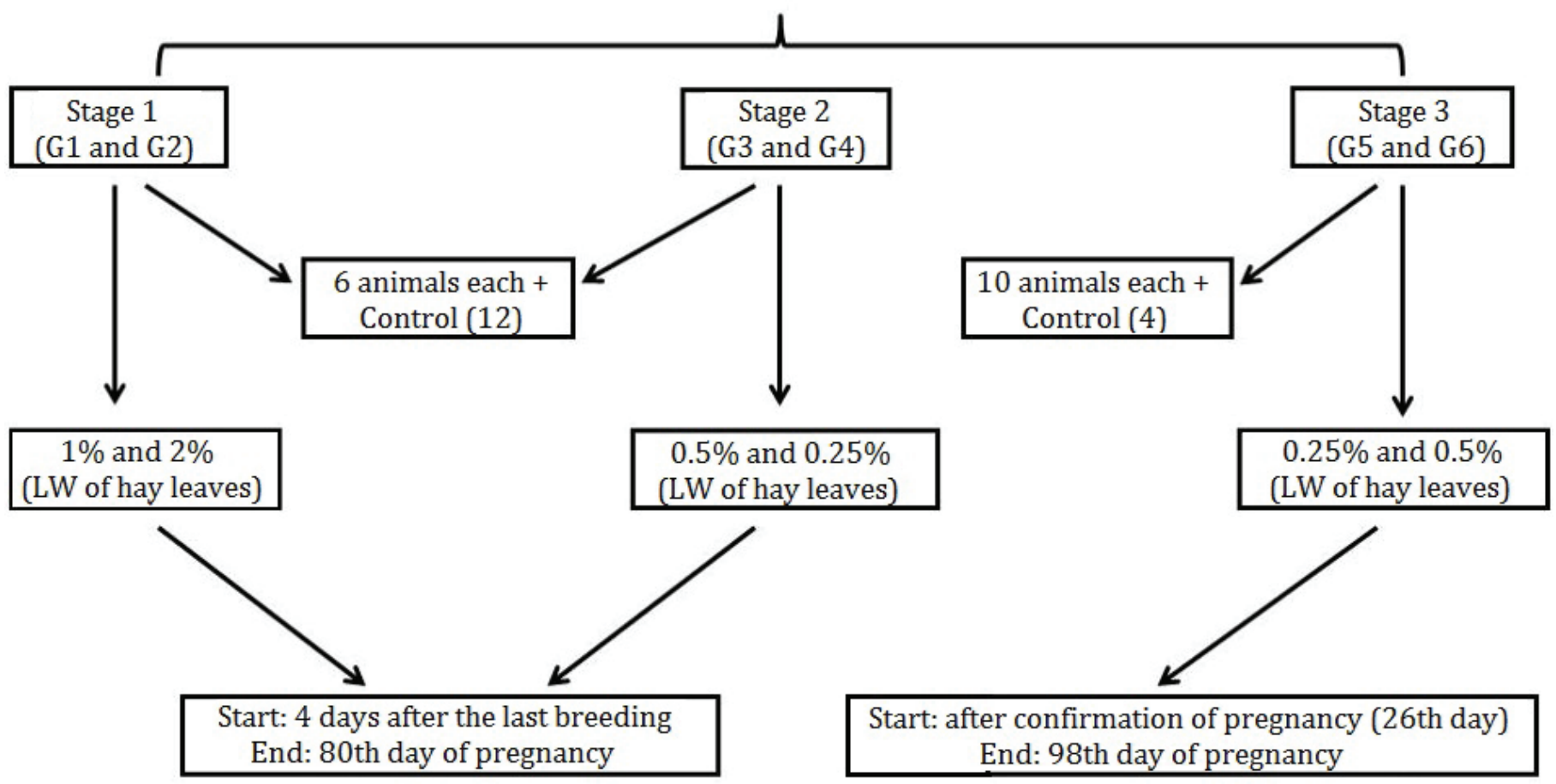

Fig.2. Flowchart of the experimental design in three stages. Live weight (LW).

Table 1. Main data on experimental design and outcome of Stage 1

\begin{tabular}{|c|c|c|c|c|c|c|c|c|}
\hline \multirow{2}{*}{ Ewe } & \multirow{2}{*}{ Dosage $^{a}$} & \multicolumn{2}{|c|}{ Consumption } & \multicolumn{3}{|c|}{ Weight (kg) } & \multicolumn{2}{|c|}{ Outcome } \\
\hline & & Total (g) & Average (g/kg/dia) & Initial & Final & Average & Diagnosis & Gestation (days) \\
\hline 0 & 1 & 13767.5 & 9.51 & 50 & 50 & 49.9 & $E L^{b}$ & 32 \\
\hline 349 & 1 & 14021.5 & 9.09 & 55 & 52 & 53.2 & EL & 32 \\
\hline 344 & 1 & 15252.5 & 8.77 & 63 & 54 & 60 & EL & 32 \\
\hline 310 & 1 & 17925.5 & 9.03 & 56.5 & 54 & 55.17 & Abortion & 39 \\
\hline 193 & 1 & 29191 & 7.16 & 48 & 39 & 43.42 & $\mathrm{NP}^{\mathrm{c}}$ & NP \\
\hline 355 & 1 & 62458 & 6.27 & 47 & 45 & 46.43 & Abortion & 46 \\
\hline 319 & 2 & 22469.33 & 16.38 & 50 & 45.5 & 47.3 & EL & 32 \\
\hline 322 & 2 & 22458.67 & 16.51 & 49 & 42.5 & 46.9 & EL & 32 \\
\hline 346 & 2 & 1383.33 & 23.46 & 49 & 37 & 40.78 & NP & NP \\
\hline 365 & 2 & 16322.67 & 14.63 & 50 & 44 & 48.5 & EL & 26 \\
\hline 100 & 2 & 17860 & 31.28 & 67 & 67 & 66.29 & Abortion & 46 \\
\hline 187 & 2 & 80800.66 & 22.91 & 52 & 40 & 44.08 & NP & NP \\
\hline
\end{tabular}



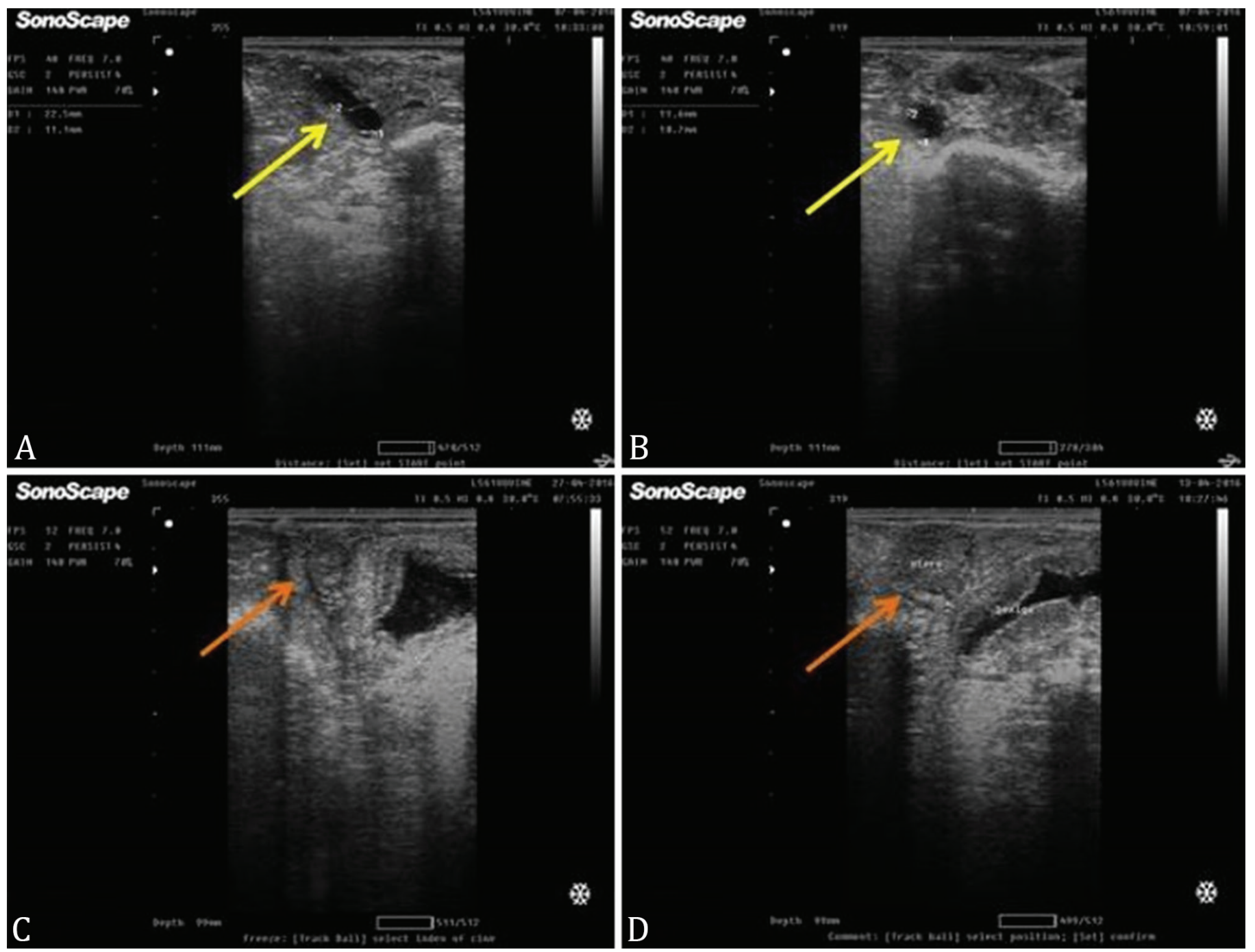

Fig.3. (A,B) Confirmation of pregnancy in animals in Groups 1 and 2, respectively (embryonic vesicle is indicated at the tip of the yellow arrows). (C,D) Confirmation of abortion (on the 46th day of gestation, ewe 355) and embryonic loss (on the 32nd day of gestation, ewe 319 ) in the previously mentioned animals, which received hay leaves of Cenostigma pyramidale in doses of $1 \%$ and $2 \%$ of live weight (LW), respectively (non-pregnant uterus indicated at the tip of the orange arrows).

leaves of Cenostigma pyramidale, could return to estrus; however, they were not pregnant after new NB.

In Stage 2, only two ewes (16.67\%) were pregnant on the 23rd day after the last NB, that is, after being confirmed by USG. The other ewe returned to estrus; however, pregnancy was not found after new NB. From G3 group ( $0.5 \% \mathrm{LW}$ of hay leaves), one ewe suffered embryonic loss at around the 40th day of gestation. A G4 ewe $(0.25 \%$ LW of hay leaves) gave birth to a stillborn fetus on the 150th day of gestation (Table 2). The stillborn fetus was necropsied, with malformations as brachygnathia inferior (underbite), scoliosis (from the cervical spine to the 13th thoracic vertebra), arthrogryposis of the four limbs and arthrogryposis of the tibial tarsal joint and fibular tarsal joint, in addition to a rudimentary tongue (Fig.4A-C). The same animal was radiographed, confirming the presence of scoliosis (Fig.5).

In Stage 3, comprising the 20 synchronized ewes, 100\% of pregnancies were found by USG around the 20th day of gestation. Placental retention was observed in $15 \%$ of the tested ewes, two from G6 group (corresponding to $20 \%$ of the group) and one from G5 (10\%). One ewe (10\%) of the G6 group suffered an abortion at approximately 108 days of gestation, accompanied by placental retention.

Malformations were observed in five lambs (45.46\%) from G6 group, of which two presented slight tortuosity of the proximal phalanges of the thoracic limbs, two presented malformations of the frontal plane of thoracic limb alignment (Fig.6A,B) and deviation of the animal tail, and one, which was aborted, presented brachygnathia superior in addition to anasarca (Fig.7).

A lamb from G5 group showed slight deformities of the four limbs. In total, 23 full-term lambs were born, 12 from G5 group and 11 from G6 group. In eight (66.67\%) lambs from G5 group, there were no changes, but in three of them $(25 \%)$, there were slight changes in an upright posture ( front posture). In five $(45.46 \%)$ lambs from G6 group, no changes were observed, and one $(9.1 \%)$ showed a slight change in an upright posture (open of the front part). There were no changes in the Control Groups. The results and the experimental design of this stage are shown in Table 3. 
Table 2. Main data on experimental design and outcome of Stage 2

\begin{tabular}{|c|c|c|c|c|c|c|c|c|}
\hline \multirow{2}{*}{ Ewe } & \multirow{2}{*}{ Dosage $^{a}$} & \multicolumn{2}{|c|}{ Consumption } & \multicolumn{3}{|c|}{ Weight (kg) } & \multicolumn{2}{|c|}{ Outcome } \\
\hline & & Total (g) & Average (g/kg/dia) & Initial & Final & Average & Diagnosis & Gestation (days) \\
\hline 344 & 0.5 & 16353 & 3.64 & 61 & 50 & 56.08 & $\mathrm{NP}^{\mathrm{c}}$ & $\mathrm{NP}$ \\
\hline 310 & 0.5 & 16511 & 3.7 & 58 & 52 & 55.71 & NP & NP \\
\hline 355 & 0.5 & $6563.75^{\mathrm{b}}$ & 3.54 & 47 & 41 & 46.33 & $E L^{\mathrm{d}}$ & 40 \\
\hline 322 & 0.5 & 14321 & 3.77 & 47.5 & 47 & 47.46 & NP & NP \\
\hline 0 & 0.5 & 15647 & 3.73 & 52 & 51 & 52.37 & NP & NP \\
\hline 100 & 0.5 & 19687 & 3.73 & 66.5 & 67 & 66.04 & NP & NP \\
\hline 346 & 0.25 & 5700 & 1.57 & 46 & 47 & 45.5 & NP & NP \\
\hline 90 & 0.25 & 5204.8 & 1.6 & 42 & 41 & 40.67 & NP & NP \\
\hline 599 & 0.25 & 4296.2 & 1.58 & 35.4 & 34 & 33.94 & NP & NP \\
\hline 349 & 0.25 & $6731.97^{b}$ & 1.58 & 54 & 54 & 53.38 & Malformed stillborn & 150 \\
\hline 365 & 0.25 & 6264.6 & 1.61 & 49 & 50 & 48.54 & NP & NP \\
\hline 193 & 0.25 & 6207.5 & 1.58 & 50 & 48 & 49.21 & NP & NP \\
\hline
\end{tabular}

a \% of live weight (LW), ${ }^{\mathrm{b}}$ total consumed until outcome, ${ }^{\mathrm{c}} \mathrm{NP}=$ non-pregnant, ${ }^{\mathrm{d}} \mathrm{EL}=$ embryonic loss.

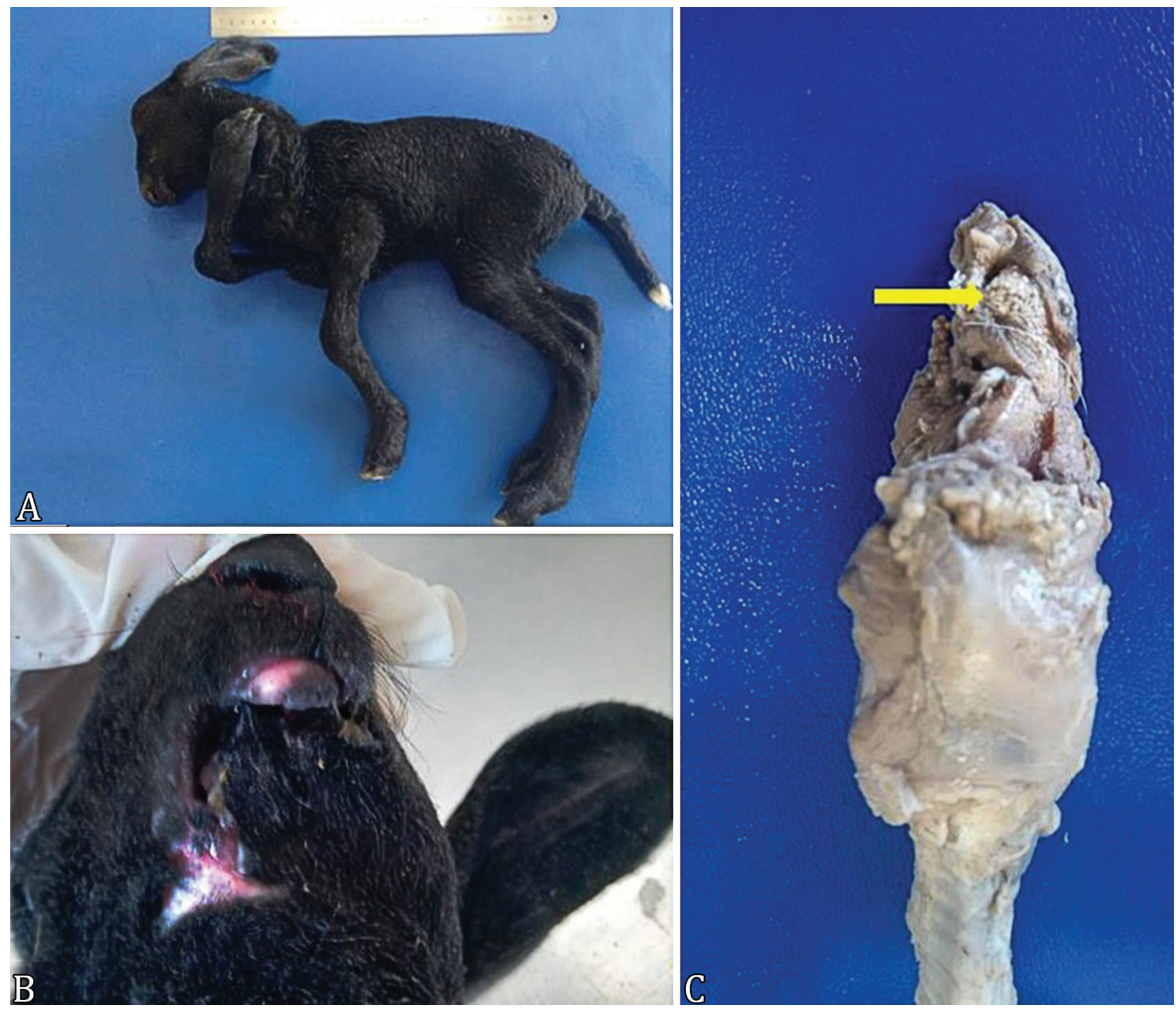

Fig.4. Stillborn of ewe 349 that ingested $0.25 \%$ of the live weight (LW) from hay leaves of Cenostigma pyramidale for 80 days. (A) Evidence of deviation of the cervical region and arthrogriposis of the four limbs. (B) Brachygnathia inferior. (C) Rudimentary tongue (arrow). 


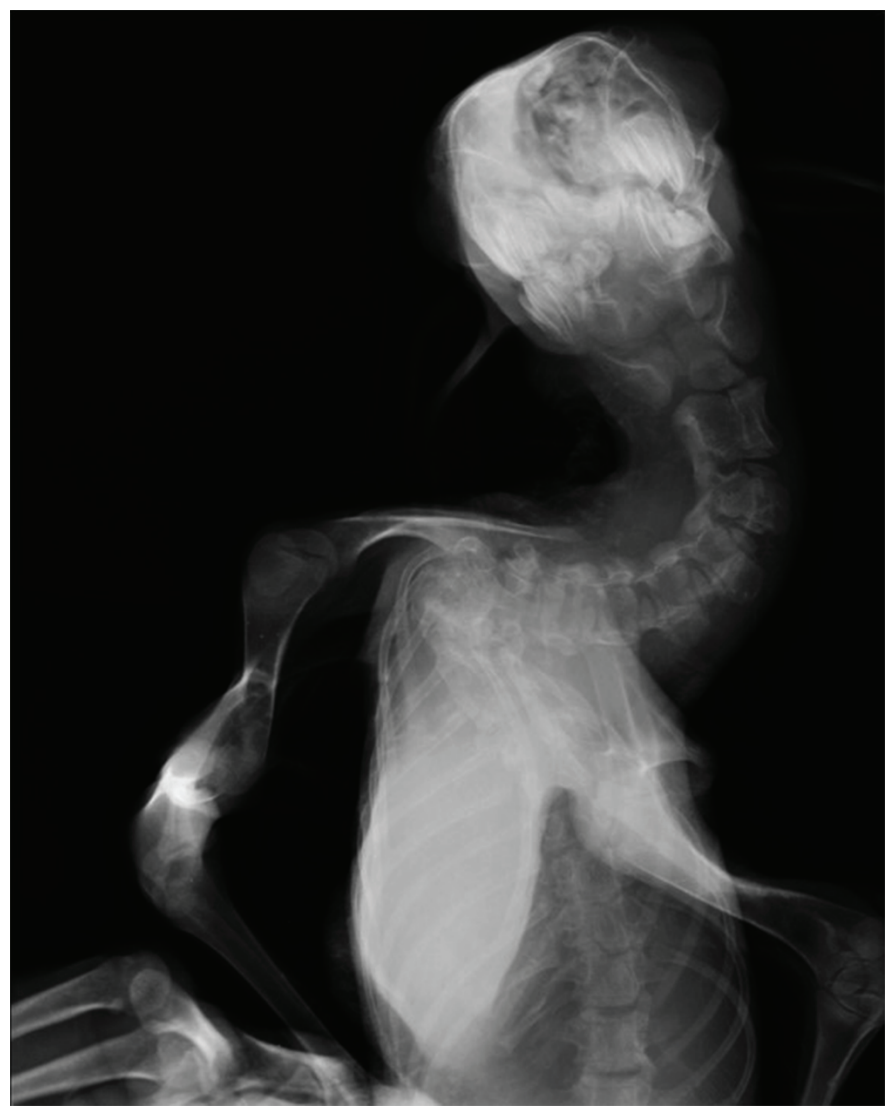

Fig.5. Dorsoventral radiography showing lateral deviation of the cervical spine, compatible with scoliosis in stillborn lamb, from ewe 349 , which received a daily dose of $0.25 \%$ of the live weight (LW) from hay leaves of Cenostigma pyramidale for 80 days.

\section{DISCUSSION}

The experimental ingestion of dry and ground leaves of Cenostigma pyramidale resulted in reproductive failures corresponding to abortion and embryonic loss, as well as malformations in ewes. These results infer that spontaneous cases of malformations and other reproductive losses in sheep and goats in the northeastern semiarid region are associated with the consumption of this species. The low acceptability of this plant, observed in experiments where it was necessary to add chemical concentrate, reinforces that poisoning is facilitated in periods of forage scarcity, remaining as the only or almost only alternative for feeding small ruminants, as reported in poisonings by other species (Tokarnia et al. 2012). On the other hand, the lesions observed are similar to those induced in small ruminants that consumed Mimosa tenuiflora ("jurema-preta") in its natural or experimental reproductive period (Pimentel et al. 2007, Dantas et al. 2010, Santos et al. 2012). Studies with $M$. tenuiflora and C. pyramidale in rats also demonstrated similar changes regarding the reproductive period (Medeiros et al. 2008, Câmara et al. 2017). As demonstrated in goats, that ingested fresh leaves of $C$. pyramidale (Reis et al. 2016), the primary malformations were also related to the limbs. The same findings were mentioned by Lopes etal. (2017), who tested doses of 10, 20 , and $40 \%$ (within $2 \%$ of the doses supplied by roughage of the animals) of dry leaves of $C$. pyramidale for three groups of four ewes from the 18th day of gestation. Of the animals that

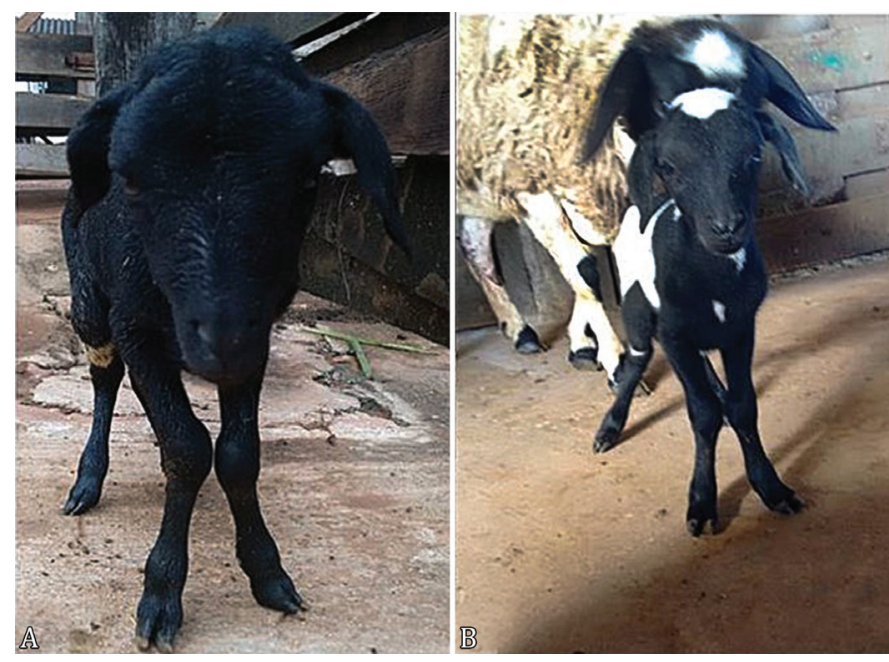

Fig.6. Lambs from mothers that ingested leaves of Cenostigma pyramidale at $0.5 \%$ of live weight (LW) for 73 days. Note tortuosity of the thoracic limbs and alteration of hock joint in pelvic limbs ("jarretes cambaios").

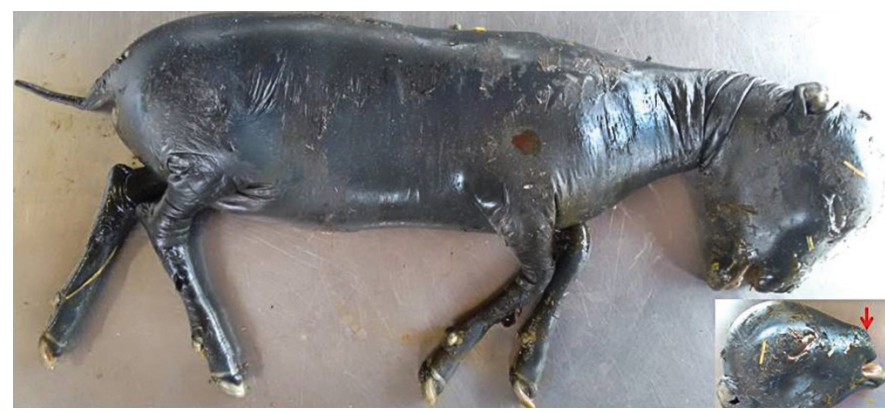

Fig.7. An aborted fetus at approximately the 108th day of gestation, whose matrix ingested daily hay leaves of Cenostigma pyramidale at $0.5 \%$ of live weight (LW) from the 26 th day of gestation. Note anasarca and brachygnathia superior (arrow).

ingested a $20 \%$ dose, three animals (75\%) had a preterm birth over 120 days of gestation, and one (25\%) gave birth to a lamb with bilateral arthrogryposis of the thoracic limbs. Concerning the group that received a $40 \%$ dose, one ewe (25\%) gave birth to a normal fetus, another one $(25 \%)$ lost the embryo on the 25 th day of gestation, one $(25 \%)$ had a miscarriage associated with arthrogryposis and prognathism over 140 days of the gestation period, and the last one $(25 \%)$ had a miscarriage of a normal fetus on the $103^{\text {rd }}$ day of pregnancy. The high rate of embryonic loss and abortion with less than 50 days of gestation seen in Stage 1 of the present study, in comparison to the aforementioned work, suggests that it results from the time of consumption of the plant (four days after the last natural harvest). According to Sinowatz (2010), when there is an action of agents that cause disturbances to the embryo in the first three weeks of life, there may be associated with embryonic loss or death, except in cases where the fetus may invoke compensatory mechanisms.

In addition to malformations, abortion, and embryonic loss, it was observed that ewes that ingested the dried leaves and leaves on the ground of $C$. pyramidale returned to estrus normally. However, when subjected to the breeding season, these ewes did 
Table 3. Main data on experimental design and the outcome of Stage 3

\begin{tabular}{|c|c|c|c|c|c|c|c|c|}
\hline \multirow[b]{2}{*}{ Ewe } & \multirow[b]{2}{*}{ Dosage $^{a}$} & \multicolumn{2}{|c|}{ Consumption } & \multicolumn{3}{|c|}{ Weight $(\mathrm{kg})$} & \multicolumn{2}{|l|}{ Outcome } \\
\hline & & Total $^{\mathrm{b}}(\mathrm{g})$ & $\begin{array}{c}\text { Average } \\
\text { (g/kg/dia) }\end{array}$ & Initial & Final & Average & Diagnosis & $\begin{array}{l}\text { Gestation } \\
\text { (days) }\end{array}$ \\
\hline 109 & 0.25 & 7369 & 2.48 & 35 & 43.8 & 35.83 & Open of the front part & 149 \\
\hline 101 & 0.25 & 9930.5 & 2.47 & 47 & 58.4 & 48.43 & Open of the front part & 150 \\
\hline 122 & 0.25 & 8941.8 & 2.44 & 44 & 47 & 44.08 & No genetic alterations & 150 \\
\hline 14 & 0.25 & 10090 & 2.46 & 50 & 60 & 49.48 & Open of the front part & 150 \\
\hline 99 & 0.25 & 8835 & 2.47 & 50 & 53.4 & 48.95 & Subtle deformities of the four limbs & 150 \\
\hline 11 & 0.25 & 11376 & 2.48 & 65 & 72.4 & 62.83 & No genetic alterations & 150 \\
\hline 5 & 0.25 & 10377 & 2.47 & 57 & 65.4 & 57.65 & No genetic alterations & 150 \\
\hline 3 & 0.25 & 9300.5 & 2.48 & 50 & 60 & 51.28 & Placental retention & 150 \\
\hline 15 & 0.25 & 9639.5 & 2.48 & 55 & 61.6 & 53.23 & No genetic alterations & 150 \\
\hline 12 & 0.25 & 10340 & 2.5 & 54 & 61.8 & 56.68 & No genetic alterations & 150 \\
\hline 108 & 0.5 & 15369 & 4.98 & 39.6 & 46.2 & 42.28 & $\begin{array}{l}\text { Partial/discrete placental retention tortuosity of the phalanges of } \\
\text { the thoracic limbs }\end{array}$ & 150 \\
\hline 1 & 0.5 & 15577 & 4.97 & 41 & 50 & 42.98 & Slight tortuosity of the phalanges & 150 \\
\hline 105 & 0.5 & 15534 & 4.96 & 42 & 51.2 & 42.93 & Tortuous thoracic limbs & 150 \\
\hline 114 & 0.5 & 17861 & 4.95 & 49 & 53.2 & 49.45 & $\begin{array}{c}\text { Abortion/placental retention/fetus with anasarca and superior } \\
\text { bragnatism }\end{array}$ & $\approx 108$ \\
\hline 76 & 0.5 & 15109 & 4.95 & 40 & 50.4 & 41.83 & Malformation of the four limbs and deviation of the animal tail & 150 \\
\hline 115 & 0.5 & 15159 & 4.94 & 43 & 52 & 42.08 & No genetic alterations & 150 \\
\hline 126 & 0.5 & 14538 & 4.92 & 39.6 & 52 & 40.48 & Hock joint injury & 150 \\
\hline 102 & 0.5 & 17447 & 5 & 47 & 53.6 & 47.83 & No genetic alterations & 150 \\
\hline 103 & 0.5 & 14923 & 4.95 & 43 & 50 & 41.34 & $\begin{array}{l}\text { No genetic alterations } \\
\text { No genetic alterations }\end{array}$ & 150 \\
\hline 10 & 0.5 & 14831 & 4.77 & 44 & 54.4 & 42.58 & No genetic alterations & 150 \\
\hline
\end{tabular}

not become pregnant. The return of estrus without pregnancy was later observed in ewe that ingested $M$. tenuiflora at the beginning of the reproductive period (Santos et al. 2012). Even after six months without ingesting C. pyramiale, it could be noted that pregnancy was not observed in $80 \%$ of the ewe submitted to the experiment in Stage 2, which suggests the possibility of a residual chemical effect of the plant. This result indicates the possibility of genetic alterations in the matrices for each offspring that ingested C. pyramidale, since studies with this species are in the initial stages and data have not yet been investigated. Likewise, there is no information regarding males, either for studies with C. pyramidale or with M. tenuiflora.

The difference at the beginning of the ingestion of $C$. pyramidale did not prevent reproductive failures. As seen in Stage 3, despite the low doses and the start of consumption occurring on the $26^{\text {th }}$ day of gestation, there were essential losses such as abortion and placental retention. The latter was not mentioned in similar studies in the northeastern semiarid region (Dantas et al. 2010, Santos et al. 2012, Lopes et al. 2017) and had not been recorded in the herd of ewes where the study was carried out. As the ewes in Stage 3 came from the Brazilian Midwest, where there is no occurrence of C. pyramidale and $M$. tenuiflora, it is suggested that the lack of contact of these animals with these plants has led to a greater predisposition to this alteration.

The geographical distribution of $C$. pyramidale and $M$. tenuiflora occurs in the northeastern semiarid region. It can be suspected that natural cases previously attributed to $M$. tenuiflora may have resulted from the poisoning by C. pyramidale. However, the possibility of synergistic action between species should not be ruled out since both can coexist in the same region. There is a possibility that the toxic principle is similar to that of M. tenuiflora, or that there is a potentization when the two species are ingested concomitantly.

\section{CONCLUSIONS}

Dry leaves and leaves on the ground of Cenostigma pyramidale maintain their toxicity, causing malformations, embryonic loss, and abortion in ewes.

Based on the observed results, it is recommended that pregnant ewe, preferably during the first $60^{\text {th }}$ day of gestation, do not ingest the plant.

Acknowledgments.- The authors would like to thank "Coordenação de Aperfeiçoamento de Pessoal de Nível Superior" (CAPES), Brazil, for the doctoral scholarship of the first author as well as all interns and employees who collaborated with the research project. The work was supported by the "Fundação de Apoio à Pesquisa do Estado da Bahia" (Proc. FAPESB PET 0006/2015), "Instituto Nacional de Ciência e Tecnologia” (INCT), and “Conselho Nacional de Desenvolvimento Científico e Tecnológico" (CNPq) regarding the "Controle das Intoxicações por Plantas" (Proc. no. 573534/2008-0) and Universal Project 2014/CNPq (Proc. no. 460979 / 2014-0).

Conflict of interest statement.- There are no conflicts of interest.

\section{REFERENCES}

Câmara A.C.L., Gadelha I.C.N., Castro M.B., Medeiros R.M.T., Riet-Correa F. \& Soto-Blanco B. 2017. Embryotoxic effects of Poincianella (Caesalpinia) pyramidalis leaves on pregnant rats. J. Vet. Diagn. Invest. 29(2):137-142. <https://dx.doi.org/10.1177/1040638716682564> <PMid:28064563> 
Dantas A.F.M., Riet-Correa F., Medeiros R.M.T., Galiza G.J.N., Pimentel L.A., Anjos B.L. \& Mora R.A. 2010. Malformações congênitas em ruminantes no semiárido do Nordeste Brasileiro. Pesq. Vet. Bras. 30(10):807-815. <https://dx.doi.org/10.1590/S0100-736X2010001000002>

Lopes J.R.G., Santos J.R.S., Medeiros M.A., Campos E.M., Riet-Correa F. \& Medeiros R.M.T. 2017. Reproductive losses caused by the ingestion of Poincianella pyramidalis in sheep. Toxicon 138:98-101. <https://dx.doi. org/10.1016/j.toxicon.2017.08.020 > PMid:28843661>

Medeiros R.M.T., Figueiredo A.P.M., Benício T.M.A., Dantas F.P.M. \& Riet-Correa F. 2008. Teratogenicity of Mimosa tenuiflora seeds to pregnant rats. Toxicon 51(2):316-319. <https://dx.doi.org/10.1016/j.toxicon.2007.06.012> <PMid:18078971>

Nóbrega Júnior J.E., Riet-Correa F., Nóbrega R.S., Medeiros J.M., Vasconcelos J.S., Simões S.V. \& Tabosa I.M. 2005. Mortalidade perinatal de cordeiros no semi-árido da Paraíba. Pesq. Vet. Bras. 25(3):171-178. <https://dx.doi. org/10.1590/S0100-736X2005000300008>

Panter K.E., Keeler R.F., Bunch T.D. \& Callan R.J. 1990. Congenital skeletal malformations and cleft palate induced in goats by ingestion of Lupinus, Conium and Nicotiana species. Toxicon 28(12):1377-1385. <https://dx.doi. org/10.1016/0041-0101(90)90154-Y>

Pimentel L.A., Riet-Correa F., Gardner D., Panter K.E., Dantas A.F.M., Medeiros R.M.T., Mota R.A. \& Araújo J.A.S. 2007. Mimosa tenuiflora as a cause of malformations in ruminants in the Northeastern Brazilian semiarid rangelands. Vet. Pathol. 44(6):928-931. <https://dx.doi.org/10.1354/ vp.44-6-928><PMid:18039908>

Reis S.D.S., Oliveira R.S., Marcelino S.A.C., Macêdo J.T.S.A., Riet-Correa F. \& Pedroso P.M.O. 2016. Congenital malformations and other reproductive losses in goats due to poisoning by Poincianella pyramidalis (Tul.) L.P. Queiroz (Caesalpinia pyramidalis Tul.). Toxicon 118:91-94. <https://dx.doi. org/10.1016/j.toxicon.2016.04.043><PMid:27125469>

Santos J.R.S., Dantas A. F. M. \& Riet-Correa F. 2012. Malformações, aborto e mortalidade embrionária causada pela ingestão de Mimosa tenuiflora (Leguminosae). Pesq. Vet. Bras. 32(11):1103-1106. <https://dx.doi. org/10.1590/S0100-736X2012001100005>

Sinowatz F. 2010. Teratology, p.339-382. In: Hyttel P., Sinowatz F. \& Vejlsted M. (Eds), Essential of Domestic Animal Embriology. Elsevier, China.

Tokarnia C.H., Brito M.F., Barbosa J.D., Peixoto P.V. \& Döbereiner J. 2012. Plantas Tóxicas do Brasil. $2^{2}$ ed. Helianthus, Rio de Janeiro. 586p.

Welch K.D., Panter K.E., Lee S.T., Gardner D.R., Stegelmeier B.L. \& Cook D. 2009. Cyclopamine-induced synophthalmia in sheep: defining a critical window and toxicokinetic evaluation. J. Appl. Toxicol. 29(5):414-421. <https://dx.doi.org/10.1002/jat.1427><PMid:19301244> 